\title{
FDI, Fiscal Decentralization and Income Inequality in China.Evidence from 1996-2012 provincial panel data
}

\author{
Wang Duoduo \\ School of Economics \\ Shanghai University \\ Shanghai, China \\ Wdd9876@163.com
}

\author{
Wang Mengtao \\ School of Economics \\ Shanghai University \\ Shanghai, China \\ wangmengtao1990@126.com.
}

\begin{abstract}
This article uses the Chinese provincial panel data from 1996 to 2012 to evaluate the effects of fiscal decentralization on FDI effect of income distribution. Our estimation results shows, in the study period, fiscal decentralization can promote the local economic development, which in general has the effects of income distribute onto.
\end{abstract}

Keywords-FDI; Capital Effect; The Technical Effect ; Fiscal Decentralization; Income Inequality

\section{INTRODUCTION}

As of 2013, China has attracted foreign investment more than $\$ 1.3$ trillions, continue to maintain the status of attracting foreign investment in developing countries. The important role of FDI in China's economic growth has been widely confirmed, but more or less ignored the FDI "distribution of the cake" the income distribution effect. In fact, as an important mode of China's entry into the international division of labor, FDI also has a profound impact on China's income distribution.

In view of China's FDI income distribution effect, the existing literature had been discussed, Wang Xiaolu, Fang Gang (2004), Zhang Guangsheng and Zhou Juan (2009), Teng Yangyang, Liu Yulin and Li Houjian (2010), Yuan Dongmei, Wei Houkai and Yang Huan (2011), Wan Guanghua, Lu Ming, Chen Zhao (2005), Zhao Shudong (2005) and so on, the FDI expanded the income gap in china. He Feng and Xu Guilin (2009), Zhan Yubo and Liu Ronghua (2010) and so on, the FDI and the income gap between the "inverted U" type of relationship, in different stages of economic development show different characteristics. The inadequacy of the literature is that the researchers are only concerned about the impact of FDI on the distribution of income in China, and the impact mechanism has not gotten enough attention.

Taking into account the important role of the Chinese government in attracting investment, we believe that the local government has a crucial impact on the impact of FDI's income distribution. An important role of local governments in promoting economic growth is attracting domestic and foreign investment, especially after the tax reform in 1994. Attracting FDI is an important aspect of the local government to attract investment, because FDI is not only beneficial to alleviate the local employment pressure (CAI, Yang, 2005; Zhang Shiwei, Zhang Xuan, 2008; Zhao Yan, Zeng Yao Zhao, 2009), but also can alleviate the local finance in the tax system of huge pressure (Cheng Xun Qin and Zhou Huixian, 2007), and help the officials to move up the corporate ladder(yuan Hai Fu, Tang Weibing, Zhan Xiang Wang, 2010). By this incentive, the local government is easy to form the "investment tendency" behavior pattern, the implementation of the capital to the owner of the policy, which leads to the income distribution to the capital, including FDI, and ultimately expand the income gap. However, the behavior of local government may narrow the income gap. Such as Tsai (1995) believes that the host government in response to the influx of FDI, it is possible to take two kinds of attitude: first, in order to pursue industrialization, the government increased fiscal spending, to provide the corresponding domestic capital, to cooperate with FDI to play a role. Thus narrowing the income gap between domestic and foreign capital; two, in the market access and other aspects of domestic enterprises or interest groups to take the attitude of protection, which will ensure that domestic enterprises in the domestic market to obtain the proceeds, which will ease the income from the other side to the FDI inflow of income inequality. Therefore, the role of local government in the FDI income distribution effect is still to be verified, this article is going to make a try in this aspect.

The structure of this paper is as follows: second data, variables and models; the third part, the empirical results; the last part is the conclusion.

\section{DATE、VARIABLE AND MODELS}

This paper studies the panel data of provinces, municipalities and autonomous regions outside, Tibet and autonomous region, and the data of Chongqing city are merged into the Sichuan province. We will be explained by the descriptive statistics of the variables and the main explanatory variables in Table 1 : 
TABLE I DESCRIPTIVE STATISTICS OF THE MAIN VARIABLE

\begin{tabular}{|l|c|l|l|l|}
\hline & Min & Max & Averge & $\begin{array}{l}\text { Standard } \\
\text { deviation }\end{array}$ \\
\hline Cityrate & $\begin{array}{c}16.7 \\
7\end{array}$ & 89.30 & 44.6435 & 16.82328 \\
\hline Gap & $\begin{array}{c}1.59 \\
92\end{array}$ & 4.7585 & 2.8490 & 0.6620 \\
\hline FD2 & $\begin{array}{c}0.92 \\
39\end{array}$ & 0.9935 & 0.9621 & 0.01461 \\
\hline fdi & $\begin{array}{c}5.11 \\
89\end{array}$ & 12748 & 1208 & 1889 \\
\hline $\mathbf{t}$ & 0 & 3 & 1.11 & 0.383 \\
\hline
\end{tabular}

In summary, we will estimate the basic equation as shown in (1):

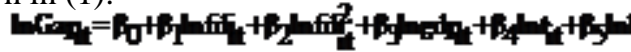

(1)

The meaning of the variables in the equations described are above, which lnfdi*FD as fiscal decentralization and FDI constitutes interaction term explanatory variables, gamma is not varying with time in individual characteristics, I epsilon is residual, the subscript $\mathrm{i}$ indicates that the corresponding area, the subscript $t$ said the year.

\section{EMPIRICAL RESULTS}

\section{A.The Impact of FDI on China's Income Gap}

We use fixed effects (FE), random effects (RE) and generalized moment estimation (GMM) to estimate the impact of FDI on China's income gap. (Length limit, only the important variables).

TABLE II THE IMPACT OF FDI ON CHINA'S INCOME GAP

\begin{tabular}{|c|c|c|c|}
\hline lngap & FE (1) & RE (2) & GMM (3) \\
\hline L1. & & & $\begin{array}{c}0.4432 * * * \\
(0.0406)\end{array}$ \\
\hline $\operatorname{lnfdi}$ & $\begin{array}{c}-0.0950 * * * \\
(0.0192)\end{array}$ & $\begin{array}{c}-0.0976^{* * *} * \\
(0.0207)\end{array}$ & $\begin{array}{c}-0.0079 * * * \\
(0.0025)\end{array}$ \\
\hline FD2 & $\begin{array}{c}-0.5279 * * * \\
(0.0840)\end{array}$ & $\begin{array}{c}-0.8379 * * * \\
(0.0820)\end{array}$ & $\begin{array}{c}-0.8594 * * * \\
(0.1024)\end{array}$ \\
\hline $\operatorname{lnfdi} 2$ & $\begin{array}{c}0.0104 * * * \\
(0.0024)\end{array}$ & $\begin{array}{c}0.0089 * * * \\
(0.0026)\end{array}$ & \\
\hline$\cdots$ & $\cdots$ & $\cdots$ & $\cdots$ \\
\hline _cons & $\begin{array}{l}-0.5014 * \\
(0.2610)\end{array}$ & $\begin{array}{c}0.4027 \\
(0.2535)\end{array}$ & $\begin{array}{l}0.5342 * \\
(0.2523)\end{array}$ \\
\hline
\end{tabular}

10 were significanticated that the significant levels of $10 \%, 5 \%$ and

As shown in Table 2, FE and RE test results show that the inflow of FDI has narrowed the income gap. After Hausman test, the $\mathrm{P}$ value is 0 , so we reject the original Being tested. hypothesis and choose the fixed effect. The coefficient of FDI in the fixed effect test is -0.095 , which is significant at the level of $1 \%$. This indicates that the increase in FDI $1 \%$ will lead to a narrowing of the income gap by $0.095 \%$. In addition, the fiscal decentralization coefficient is significantly negative, which shows that fiscal decentralization has the function of reducing the income gap. We have used the Generalized of Moments GMM (Method) to examine the possible problem of endogenous nature. Table 2 (3) shows that the income gap of the 1 order lag coefficient is 0.4432 , and the level of $1 \%$ is significantly positive. FDI and fiscal decentralization are still significantly negative at the $1 \%$ confidence level. The absolute value of FDI system is decreased, and the absolute value of the coefficient of fiscal decentralization is increased.

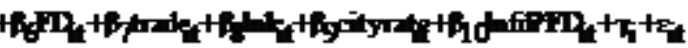

B. Does FDI Through Fiscal Decentralization Affect the Income Gap?

Now, by introducing the interaction term between FDI and fiscal decentralization, we test the conclusions of the above, and the results are reported in Table 3(length limit, only the important variables).

\begin{tabular}{|c|c|c|c|}
\hline \multirow{3}{*}{$\begin{array}{l}\text { Ingap } \\
\text { t1. } \\
\text { Infdi }\end{array}$} & \multirow[t]{2}{*}{ fe } & \multirow[t]{2}{*}{ re } & \multirow{2}{*}{$\begin{array}{c}\text { GMM } \\
0.4617^{* * *} \\
(0.0437)\end{array}$} \\
\hline & & & \\
\hline & $\begin{array}{c}-0.0805^{* * *} \\
(0.0205)\end{array}$ & $\begin{array}{c}-0.0779 * * * \\
(0.0215)\end{array}$ & $\begin{array}{c}-0.0506 * * \\
(0.0288)\end{array}$ \\
\hline FD2 & $\begin{array}{l}-0.1415 \\
(0.2135) \\
\end{array}$ & $\begin{array}{l}-0.2245 \\
(0.2244)\end{array}$ & $\begin{array}{c}-1.3989 * * * \\
(0.3651) \\
\end{array}$ \\
\hline InfdifDZ & $\begin{array}{c}-0.0866^{* *} \\
(0.0440)\end{array}$ & $\begin{array}{c}-0.1300 * * * \\
(0.0451)\end{array}$ & $\begin{array}{c}0.1148 \\
(0.0759)\end{array}$ \\
\hline Infdi2 & $\begin{array}{c}0.0131^{* * *} \\
(0.0028)\end{array}$ & $\begin{array}{c}0.0133 * * * \\
(0.0030)\end{array}$ & \\
\hline$\ldots$ & $\cdots$ & $\cdots$ & $\cdots$ \\
\hline -cons & $\begin{array}{c}-0.5887^{* *} \\
(0.2639)\end{array}$ & $\begin{array}{c}0.1980 \\
(0.2588)\end{array}$ & $\begin{array}{c}0.7829 * * \\
(0.3020)\end{array}$ \\
\hline \multicolumn{4}{|c|}{$\begin{array}{l}\text { Note: } * * * * * * \text { indicated that the significant levels of } 10 \%, 5 \% \text { and } \\
1 \% \text { were significant, and the standard error was within the brackets. } \\
\text { After the introduction of FDI and fiscal } \\
\text { decentralization, the test results show that the interaction } \\
\text { between FDI and fiscal decentralization is significantly } \\
\text { negative. However, this result is not supported by the } \\
\text { GMM test. GMM test results show that the interaction of } \\
\text { FDI and fiscal decentralization is positive, but not } \\
\text { significant. This shows that, after taking into account the } \\
\text { internal nature, the overall level of fiscal decentralization } \\
\text { does not effectively improve the income distribution effect } \\
\text { of FDI, so the relevant conclusions need to be further }\end{array}$} \\
\hline
\end{tabular}




\section{IV.CONCLUSIONS}

In this paper, we find that FDI can influence the income inequality through fiscal decentralization in the 1996-2012 years of China's inter provincial panel data. In general, the FDI and the fiscal decentralization can ease the income inequality. This study from the perspective of the literature supporting the inflows of FDI will eventually help to improve income distribution pattern of the host country perspective, the results obtained depends on the host country with strong economic development as a support.

This paper has important policy implications for the future development of China's economy. At present, the Chinese economy is undergoing structural adjustment and industrial upgrading, one of the important content is to guide the manufacturing industry to the central and western regions of the central and western regions of the central and western regions, which also includes FDI related industries. According to the above research conclusion, we expect this strategy not only can bring more good economic development opportunities, but also improve the income distribution pattern of these regions, and narrow the income gap between regions and regions. During this period, the maintenance of the healthy competition between local governments will play an important role, which means that in the transformation of government functions and to maintain local economic activity to find a good balance point.

This paper also has some shortcomings: first, it is limited by the available data, the use of urban and rural resident's income ratio as the overall income gap measurement is not accurate; second, only tuse the inter provincial level data to analyze, will lead to FDI for the same province, the impact of the income gap can not be tested. The above problems depend on further analysis to solve.

\section{REFERENCES}

[1] Chen Yanying, Dong Xu. The difference of FDI location choice between service industry and manufacturing industry -- Empirica Research Based on the stock adjustment model [J], world economic research, 2013 (03):53-58+88-89.

[2] Xu Yongsheng, Qiao Baoyun. Measurement of fiscal decentralization. Empirical analysis of [J], economic research, 2012 (10): 4-13.

[3] Zhan Yubo, Liu Ronghua. Technology innovation of Chinese domestic enterprises is how to achieve? From the large and mediumsized industrial enterprises at the provincial level panel evidence [J], world economic forum, 2010 (1): 50-63.
[4] yuan Hai Fu and Tang Weibing, Zhan Xiang Wang. FDI spillover mechanism, the path of technological progress and economic growth performance [J], economic research, 2010 (06) : 92-104.

[5] Qiyun Fang,Yao Liu. Empirical Analysis. Business Cycles and Inward FDI in China[J], American Journal of Applied Sciences, 2007:410

[6] Moller Stephanie, Nielsen François,Alderson Arthur S. Changing patterns of income inequality in U.S. counties, 1970-2000.[J]. American Journal of Sociology,2009:1144.

[7] Choi, C. Does foreign direct investment affect domestic income inequality[J], Applied Economic Letters,2006(13). 811-814.

[8] Wei, K. L., S. J. Yao and A. Liu.FDI and Regional Inequality in China, 2007

[9] Chang Kai, Qiao Jian. China labor relations report. Beijing: China Labor and Social Security Publishing House, 2009。

[10] Wooldridge, Jeffery M. “App lications ofGeneralizedMethod ofMoments Estimation " Journal of Economic Perspectives, 2001,15(4):87-100

[11] Tsai, P-L.Foreign direct investment and income inequality. further evidence[J]. World Development. 1995(23). 469-483.

[12] Wooldridge, Jeffery M. “App lications ofGeneralizedMethod ofMoments Estimation " Journal of Economic Perspectives, 2001,15 (4) : 87 - 100.

[13] Wei, K. L., S. J. Yao and A. Liu.FDI and Regional Inequality in China, 2007

[14] World Bank, Sharing Rising IncomesDispari ties In China Washington D. C,1997.

[15] Wei, S.-J. and Wu, Y. Globalization and inequality. evidence from within China, NBER Working Paper, 2001(8):611.

[16] Nigel Driffield,Karl Taylor.Are foreign firms more technologically intensive? UK Establishment evidence from the ARD [J]. Scottish Journal of Political Economy,2005. 521.

[17] Oates W.E. Searching for Leviathan An Empirical[J], American Economic Review,1985(75):748-757.

[18] Qiyun Fang,Yao Liu. Empirical Analysis. Business Cycles and Inward FDI in China[J], American Journal of Applied Sciences, 2007:410.

[19] Rubinson, R. The world economy and the distribution of income within states. a cross-national study[J], American Economic Review 1976(41). 638-659.

[20] Li and Xu.Trade, Foreign Investment, and China' s Wage Inequality,2003.

[21] Lin J.Y and Z . Liu. Fiscal Decentralization and Economics Growtlls in China[J], Economics Development and Cultural Change,2000(49):1-22.

[22] Moller Stephanie, Nielsen François,Alderson Arthur S. Changing patterns of income inequality in U.S. counties, 1970-2000.[J]. American Journal of Sociology,2009:1144.

[23] Feenstra, R. C. and Hanson, G. H. Foreign direct investment and relative wages. evidence from Mexico's maquiladoras[J], Journal of International Economics, 1997(42). 371-393.

[24] Jon D. Haveman,Alan V. Deardorff,Robert M. Stern. Sectoral effects of reductions in NATO military expenditures in the major industrialized and developing countries[J], Open Economies Review,1993,pp43. 